\title{
Developing a New Philosophy of Water Rights
}

\author{
Edward F. Treadwell*
}

No survey of the Central Valley Project can be complete without
an examination of the California water law, particularly developments since the 1928 amendment to Article XIV of the constitution including the important recent decision of the United States Supreme Court in the case of United States v. Gerlach Live Stock Co. ${ }^{1}$ Congress in authorizing various portions of the Central Valley undertaking has provided that the reclamation law will govern the project. ${ }^{2}$ Reclamation law declares: ${ }^{3}$

That nothing in this Act shall be construed as affecting or intended to affect or to in any way interfere with the laws of any State or Territory relating to the control, appropriation, use, or distribution of water used in irrigation, or any vested right acquired thereunder, and the Secretary of Interior, in carrying out the provisions of this Act, shall proceed in conformity with such laws, and nothing herein shall in any way affect any right of any State or of the Federal Government or of any landowner, appropriator, or user of water in, to, or from any inter-state stream or the waters thereof.

To fully understand the California law, one must know its involved background as developed in endless bitter litigation. ${ }^{4}$ But for the purpose of this paper it may be said that the 1928 amendment to the constitution was the culmination of a long struggle between the common law riparian rights philosophy and the mimers' custom of appropriation. The riparian rights doctrine, developed where lands were

* Member of the San Francisco bar; author of Annotated Constitution of CatrFORNIA (6th ed. 1931); The CatTLE KING (2d ed. 1950).

1339 U.S. 725 (1950).

2 E.g. 61 STaT. 475 (1947).

32 Star. 390 (1902), as amended, 43 U.S. C. $\$ 383$ (1946).

4 See Wies, Water Rights in the Western States (3d ed. 1911); Shaw, The Development of the Law of Waters in the West, 10 CAIIF. L. REv. 443 (1922).

Tulare Dist. v. Linsay-Strathmore Dist., 3 Cal. 2d 489, 45 P. $2 \mathrm{~d} 972$ (1935) is an example of the complexity of such litigation. The case first came before the Supreme Court on its merits 18 years after its commencement and was then sent back for retrial. The first trial had consumed 200 court days and the record included a reporter's transcript of 26,936 pages and 678 exhibits. Counsel consumed over five years in preparing the appellate briefs. 
amply watered by rainfall, was that each riparian owner has the right to have the water flow down to him in its natural volume unimpaired in quality. This doctrine was superimposed on the miners' custom of appropriating waters as needed. Where other western states rejected riparian rights, California courts spent many decades trying to reconcile the two conflicting philosophies. The Twentieth Century with its gigantic power and irrigation projects and increasing urban needs focused attention on the problems of conservation and maxinum utilization of the limited water resources.

However, in 1926, the Supreme Court of California in Herminghaus v. Southern California Edison Company, ${ }^{5}$ served nore firmly to establish the rule that a riparian owner was entitled to the full flow of the stream and was not limited by any rule of reasonableness. In that case the owners of the Herminghaus Ranch established that it was traversed by sloughs taking water out of the San Joaquin River at such elevations that it required between 4000 and 10,000 cubic feet of water per second in the river before water would flow into the sloughs, and that the entire flow of the river was useful in flowing water through the sloughs and overflowing the land for the production of grasses valuable for livestock. They claimed that they were entitled to the full flow of the stream, amounting to $1,800,000$ acre feet per year. The court upheld this contention despite the established fact that if reasonable nuethods of diversion and distribution were installed a flow of 180 cubic feet per second during the growing season would be ample for the irrigation of the land.

It was obviously for the purpose of nodifying this rule that the people of the state adopted the 1928 aniendment. In the official pamphlet circulated to all voters, the proponents of the measure discussed the Herminghaus case saying: ${ }^{6}$

Under present interpretations the riparian owner is not bound by any rule of reasonableness in the use of water.

For example, in the Herminghaus case it was held that approximately 97 per cent of the water of the streams should flow by the land, in order that 3 per cent might be used for irrigation.

5 200 Cal. 81, 252 Pac. 607 (1926). Earlier, the Water Commission Act (Cal. Stats. 1913 , p. 1012) had attempted to limit the riparian right to a reasonable use of water. The Herminghaus case held Section 42 of the Act could not validly be applied to impair the vested rights of a riparian owner. A similar result was reached in Fall River Irr. Dist. v. Mt. Shasta Power Corp., 202 Cal. 56, 259 Pac. 444 (1927), where the court recognized that the riparian right might yield to the police power, but felt that the Act did not purport to be an exercise of such power.

${ }^{6}$ Cac. Sec. State, Amembments to Constitution and Proposed Statutes 4 (1928). 
They contended that the development of California required a different rule. The proposed amendment would preserve to the riparian owner all the water to which he might be entitled for beneficial use by reasonable nethods, but would require that needless or unwarranted waste be prevented. It was stated that the new amendment would change "the present theory of the law that now permits the unused, unrestrained and undiminished flow of our streams to the sea."

\section{The amendment provides: ${ }^{7}$}

It is hereby declared that because of the conditions prevailing in this State the general welfare requires that the water resources of the State be put to beneficial use to the fullest extent of which they are capable, and that the waste or unreasonable use or unreasonable method of use of water be prevented, and that the conservation of such waters is to be exercised with a view to the reasonable and beneficial use thereof in the interest of the people and for the public welfare. The right to water or to the use or flow of water in or from any natural stream or water course in this State is and shall be limited to such water as shall be reasonably required for the beneficial use to be served; and such right does not and shall not extend to the waste or unreasonable use or unreasonable method of use or unreasonable method of diversion of water. Riparian riglits in a stream or water course attach to, but to no more than so mucl of the flow thereof as may be required or used consistently with this section, for the purposes for which such lands are, or may be made adaptable, in view of such reasonable and beneficial uses; provided, however, that nothing herem contained shall be construed as depriving any riparian owner of the reasonable use of water of the stream to which his land is riparian under reasonable methods of diversion and use, or of depriving any appropriator of water to which he is lawfully entitled. This section shall be self-executing, and the Legislature may also enact laws in the furtherance of the policy in this section contained.

This anendment became the fountainhead of California water law. Twenty-two years have passed since its enactment, and this paper proposes to consider how far it has affected the rights of the riparian owner under varying conditions.

One of the first important cases involving the amendment was the superior court case of Miller \& Lux, Inc. v. Madera Irrigation Dis-

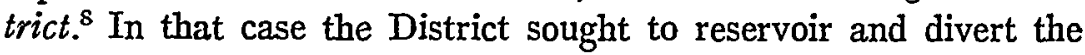

T CaL. Const. ART. XIV, \& 3 (Treadwell 1931).

8 Miller \& Lux, Inc. v. Madera Irrigation District, Superior Court, Fresno County, No. 25729, and San Luis Canal Company v. Madera Irrigation District, Superior Court, Fresno County, No. 25731 (1933). The significance of the case is brought out at notes 
winter and spring floods of the San Joaquin River. Miller \& Lux, the plaintiff, claimed the right to the same floodwaters to fill the slough channels of the river and to overflow its lands for the production of grasses for livestock. The evidence showed that the sloughs took water only at high stages of the river and that the greater the flow, the more land flooded and grass produced. The case was therefore very much like the Herminghaus case, and the question was presented whether under the 1928 amendment the riparian rights extend to such a method of flood irrigation. Judge Haines held that they did, excepting flows in excess of certain amounts. The District did not appeal, which might be interpreted as indicating that its legal advisers felt the amendment would not be held to deprive a riparian owner of this type of beneficial use irrespective of the claims of its economic unreasonableness.

The question of the validity, meaning and effect of the amendment first came before the California Supreme Court in 1933 in the case of Gin S. Chow v. Santa Barbara.9 The trial court had denied an injunction sought by the riparian owner against the storage by a municipal corporation of water of the Santa Ynez River, a coastal range stream fed by rainfall and not by snow. The defendant did not seek to divert all the water, but only certain flood waters. These flood waters were found to be extraordinary flows within the meaning of the pre-amendment case of Gallatin v. Corning Irrigation Company, ${ }^{10}$ which did not belong to the riparian owner. The trial court also found that the water intended to be impounded was in excess of all the water that could be beneficially used by the plaintiff and no injury wonld result to the plaintiff by the storage of the waters.

In answer to plaintiff's contention that however small the invasion, it should be enjoined, the Supreme Court held that whatever the rule prior to the amendnient, that was no longer the law. The purpose of the amendment was to conserve the waters of the state "without interference with the beneficial uses to which such waters may be put by the owners of water rights, including riparian owners," and here the water "was of no substantial benefit to the riparian owner." 11 The

34 and 45, infra. Collier v. Merced Irrigation District, Superior Court, Merced County (1931), an earlier superior court case had held that the amendment in no way changed or modified the riparian right to have the river flow high enough to seep into the land for the growth of alfalfa.

9217 Cal. 673, 22 P. 2 d 5 (1933).

$10163 \mathrm{Cal} .405,126$ Pac. 864 (1912).

11 Gin S. Chow v. Santa Barbara, supra note 9 at 700, 22 P. 2 d at 16. 
court pointed out that while the amendment was not intended to destroy a right, its effect was to limit the riparian owner to "a reasonable, beneficial use." ${ }^{12}$ Such reasonable beneficial use is a question of fact in each case for the trial court, and since there was no substantial or any benefit under the facts of this case the use was unreasonable. ${ }^{13}$

The scope of the amendment again came before the Supreme Court of California in Peabody v. City of Vallejo, ${ }^{14}$ a case decided in the trial court in 1929 prior to the Gin S. Chow case. The City of Vallejo claimed the right to store storm and freshet waters in excess of the normal flow of the stream. The trial court found that all of the waters of the streams were part of the normal flow and were beneficially used by the plaintiffs, and enjoined the city from storing the waters.

The Supreme Court thought that the case had been decided without regard to the 1928 amendment. The court stated the extreme views of the parties, the plaintiffs claiming the right to the full flow of the stream without diminution, regardless of the unreasonableness of such use and regardless of waste or surplus which such use might entail, and the defendant insisting that plaintiffs were only entitled to the ordinary, as distinguished from flood or freshet flow. The court stated that the general effect of the amendment was the doctrine of reasonable use, the problem being to "apply these rules in the varying circumstances of cases as they arise."15 The court held that the water might be stored "subject to the rights of those who have a lawful priority in a reasonable beneficial use."16

The court went on to aumounce that the distinction between ordinary and extraordinary floods was no longer applicable. The appropriator can only take the surplus over the water beneficially used by the riparian owner. Where, because of ramstorms and resulting floods, melting snows, or of natural flow otherwise, a large volume of water flows to the sea unused, wasted and lost, the problem of how to conserve it having due regard for riparian owners and prior appropriators must be dealt with in connection with each case as it arises. But the

12 Gin S. Chow v. Santa Barbara, supra note 9 at 704, 22 P.2d at 17.

13 The court favorably cited Hilbert v. City of Vallejo, 19 F.2d 510 (D.C.N.D. Cal. 1927), a pre-amendment case which also involved a flashy coastal stream fed by rains and not by snow. The Hilbert case was decided on the Gallatin case theory that the waters were not part of the regular flow of the stream but constituted extraordinary flows, the taking of which was not within the riparian right and did not appreciably affect or substantially injure the riparian owner.

142 Cal. 2d 351, 40 P.2d 486 (1935).

15 Id. at 368,40 P. $2 d$ at 491 .

16 Id. at 368,40 P. $2 \mathrm{~d}$ at 492 . 
right to the waste of water is no longer included in the riparian right.

On the basis of the facts before it, the court held that overflow merely to deposit silt or to remove salt was not even within the riparian right at common law, and involves an unreasonable use under the constitution. The asserted right to have flood and freshet waters overflow the lands and never return to the stream cannot be supported. ${ }^{15}$ The right to the full flow to maintain the underground and percolating water supply is recognized "as a 'natural' right analogous to the riparian right, but subject to the limitations of the new state policy."18 This right is to be handled on the same basis as a right of overlying landowners in percolating waters as against an appropriator for distant land, namely that the appropriator can only take a surplus over the needs of the overlying landowner. It is further subject to the rule of reasonable use.

The court, however, recognized that there were certain safeguards both of riparian and appropriative rights. It stated: ${ }^{19}$

There is and should be no endeavor to take from a water right the protection to which it is justly entitled. The preferential and paramount rights of the riparian owner, the owner of an underground and percolating water right, and the prior appropriator are entitled to the protection of the courts at law or in equity.

The owner of such a right is entitled to injunctive relief against the assertion of an adverse use which might otherwise ripen into a prescriptive right. In a case where an injunction is not proper he is entitled to a judgment declaring his preferential and paramount rights. While the technical infringement of the right is not actionable, if the appropriative right causes a substantial diminution of the supply, the owner is entitled to compensation for the resulting damage to his lands. "Any use by an appropriator which causes substantial damage

17 In this connection the court referred to Montecito Valley Co. v. Santa Barbara, $144 \mathrm{Cal} .578,77$ Pac. 1113 (1904), an apparent miscitation since there seems to be nothing on the subject in that case.

18 Peabody v. City of Vallejo, supra note 14 at 370, 49 P.2d at 492. Certainly there is no injury if there is no appreciable lowering of the water table. Id. at 375,40 P. $2 \mathrm{~d}$ at 495 .

The court also recognized the right to the pressure of the stream to force water underground as an aspect of the overlying landowner's right and analogous to the riparian right. But this right too is subject to the test of reasonable use. "It would seem to be obvious that the use of an entire flood and freshet flow of a stream to press a small amount of water into adjoining lands would be an unreasonable use ... ." Id. at 375, 40 P. 2d at 495.

$19 \mathrm{Id}$. at 374,40 P. $2 \mathrm{~d}$ at 494. 
thereto, taking into consideration all the present and reasonably prospective recognized uses, is an impairment of the right for which compensation must be made ...."20

The court concluded that the amendment rule of reasonable use applies to all water rights, whether grounded on riparian rights or the analogous rights of the overlying landowner, the percolating water right or the appropriative right. Since the test of reasonable use had not been applied to the facts, the case was remanded for trial as a condemnation action. If plaintiffs were not damaged substantially by defendant's storage they would be entitled to a judgment declaring their rights and enjoining adverse rights. As an alternative they could have compensation for extinguishment of their paramount rights. Or if there were substantial damages taking into account the test of reasonable use the plaintiffs should be compensated. The trial court has the power to make reasonable regulations for the use of the water by the respective parties and, if appropriate, find a physical solution which will minimize or eliminate damages. ${ }^{21}$

Shortly thereafter the case of Meridian, Ltd. v. San Francisco reached the Supreme Court of California. ${ }^{22}$ Plaintiff, a riparian owner, sought to enjoin the proposed taking of water by the defendant city from the Tuolumne River for storage in the Hetch Hetchy reservoir. The case did not involve any right to the benefit of overflow, the plaintiff's land being cultivated and the amount of water reasonably necessary therefor being proved without dispute. Notwithstanding this, the trial court enjoined the defendant appropriator from storing water of the stream on the theory that the location of the storage was so far removed from the plaintiff's lands that it would be impossible for the plaintiff to know that the storage was without interference to his rights. In reversing, the Supreme Court referred to the amendment as limiting the right of the riparian owner to the amount of water reasonably required. It stated that the scope of the amendment can only be determined by a large number of cases presenting different conditions. Certainly "the riparian owner has a prior and paramount right

20 Peabody v. City of Vallejo, supra note 14 at 374-375, 40 P. 2d at 495.

21 One of the plaintiffs was the town of Suisun which pumped water in dry years to the amount of some .37 of an inch. While the defendant city did not have a power of eminent domain over this property right of the town, the court reversed the absolute injunction suggesting as an alternative the declaring of a prior right or even a duty on the defendant to supplement the town's water supply to the extent of the loss.

2213 Cal. 2d 424, 90 P. $2 d 537$ (1939). 
to this use and if necessary is entitled to the full natural flow of the stream ...."23

The court pointed out that to permit waters to pursue their natural course to the sea is not waste in the constitutional sense. It noted that storage by the Central Valley Project is a beneficial use within the amendment but even "such right of storage must necessarily be subordinate to all beneficial uses on the stream made in the exercise of riparian and prior appropriative rights." 24

Other cases have made it clear that where appropriative rights substantially damage or diminish preferential rights, and where injunction is improper, there must be compensation. Thus in Hillside Water Co. v. Los Angeles ${ }^{25}$ the court overruled an injunction and sent the case back for retrial as a reverse condemnation proceeding. Plaintiff was to be compensated for the detriment to its lands and water table resulting fron defendant's pumping operations. ${ }^{26}$ Determination of damages was said to be difficult but not impossible, the range being somewhere between a nominal sum and the market value of the land.

The courts have been zealous in requiring compensation even where relatively secondary rights are concerned. For example, compensation must be paid where drainage of a lake destroys the recreational attractions greatly reducing the value of the land. ${ }^{27}$ Similarly

$23 \mathrm{Id}$. at $445,90 \mathrm{P} .2 \mathrm{~d}$ at 547 .

24. $I$. at $449-450,90$ P. $2 \mathrm{~d}$ at 549.

27 10 Cal. 2d 677, 76 P. 2d 681 (1938).

26 Plaintifi claimed a right to have the underground water table maintained in its natural state despite an abundant supply of water for surface irrigation. The court recognized that such an underground supply would act as an undersupport for irrigation and would also minimize the requirements for surface irrigation. Vegetation would not grow as abundantly because of the lower temperature of surface irrigation water and changed soil conditions. Therefore the use was beneficial and reasonable.

A case involving wells furnishing a municipal water supply was sent back for a determination as to what extent the water level could be reduced without substantial danger to the city's water supply. The decree was to be reframed to require the defendant to maintain the levels of plaintiff's wells above the danger level. City of Lodi v. East Bay Mun. Utility Dist., 7 Cal. 2d 316, 60 P.2d 439 (1936).

Again the court carefully himited the extent of interference:

Although the prior appropriator may be required to make minor changes in its method of appropriation in order to render available water for subsequent appropriators, it cannot be compelled to make major changes or to mcur substantial expeuse. Id. at 341,60 P.2d at 450.

27 Los Angeles v. Aitken, 10 Cal. App. 2d 460, 52 P. 2 d 585 (1935). The court recognized the right to use, regulate and control the waters for navigation, but denied a right to convert them or authorize their conversion for other purposes. Such a diversion requires the exercise of the right of eminent domain and the making of just compeusation. "The equitable and well-established doctrine of eminent domain should not be 
the owner of a right to have sand and gravel washed upon his property by the normal flow of a stream must be compensated where the stream is to be converted into a concrete channel for flood control purposes. ${ }^{28}$

These cases had commenced to evolve a new doctrine of riparian rights. Yet at the same time they served to emphasize the limited effect of the 1928 amendment. It has been said: ${ }^{29}$

In no case has the Court denied both an injunction and compensation to a riparian on the ground that there was a wasteful or unreasonable use or method of use of water. In three cases ${ }^{30}$ the specific use claimed by the riparian was held to be unreasonable or to involve an unreasonable method. Although an injunction against the upstream appropriator was denied in all three cases, in no case was compensation expressly denied.

... If the riparian can show a beneficial use of water, a right attaches. The deprivation of this right entitles him to compensation. The amendment's primary effect has been to prevent the issuance of injunctions that would cause a waste of water. Thus in each of the cases noted the Court cited the 1928 amendment in denying the injunction. However, the courts also stressed that the appropriation was to a public use. This in itself may have been sufficient basis for denying an injunction since presumably the appropriator in each case had the power of eminent domain.

It was with this background as to the meaning and effect of the 1928 aniendment that the Gerlach cases came before the Court of Claims $^{31}$ and the Supreme Court of the United States. ${ }^{32}$ Both courts struggled with the problem of determining the law of California and each decision deserves careful study. The mere fact that the decision

invaded in the guise of the exercise of police powers so as to deprive individuals of their property rights without just compensation." Id. at 468, 52 P.2d at 589 . See City of Elsinore v. Temescal Water Co., 36 Cal. App. 2d 116, 97 P.2d 274 (1939), which also recognized that maintenance of the level of a lake for the benefit of adjacent recreational lands was a reasonable use under the constitution.

28 Los Angeles County F. C. Dist. v. Abbot, 24 Cal. App. 2d 728, 76 P.2d 188 (1938).

This was a valuable property right; and under our system of government an attempted invasion of the established doctrine of eminent domain in the guise of the exercise of police powers, so as to deprive individuals of their property rights without just compensation, finds no countenance. $I d$. at 736, 76 P. $2 \mathrm{~d}$ at 193.

29 Comment, 1 Stan. L. REv. 172, 175-177 (1948).

30 Peabody, supra note 14; Hillside Water, supra note 25; City of Lodi, supra note 26.

31 Gerlach Live Stock Co. v. United States, 76 F. Supp. 87, 99 (Ct. Cl. 1948).

32 United States v. Gerlach Live Stock Co., 339 U. S. 725 (1950). 
of the Supreme Court becomes the last word does not remove the importance of the decision of the Court of Claims. The Supreme Court of California could reject either or both where local law is at issue.

The Gerlach cases grew out of the Central Valley Project. The plaintiffs owned parcels riparian to the San Joaquin River which are known as "uncontrolled grass lands" to distinguish them from "controlled grass lands" and other crop lands which are irrigated through controlled systems. Each year the stream swells and submerges and saturates the lands, enriching them so that forage and pasturage thrive, as otherwise they cannot. Plaintiffs claim the right to enjoy without hindrance a natural, seasonal fluctuation which presupposes a peak flow otherwise largely unutilized. The Court of Claims found that the seasonal floods made three acre feet of water available for each acre of grass land. One-third of this was absorbed by the land, and the balance drained back into the stream where it was available for lower riparian owners and to prevent the incursion of salt water from the San Francisco Bay.

The project puts an end to all this since, except at rare intervals, there will be no spill over the Friant Dam and the bed of the San Joaquin along the plaintiffs' lands will be parched and their lands will be barren. The plaintiffs claimed conpensation for the taking of the annual inundations on the theory that they were part of the natural flow of the streain and the continuance was a right annexed to their property.

The Court of Claims easily disposed of the contention that under its navigation and flood control powers the government does not have to compensate for the destruction of riparian rights, and held that there was liability for whatever rights the plaintiffs had..$^{33}$ The court then had to face the more troublesome problem of whether the plaintiffs owned water rights under California law.

The court noted that in previous litigation these lands had been held to be riparian and that the identical rights had been sustained in the unappealed case of Miller \& Lux, Inc. v. Madera Irrigation District. ${ }^{34}$ Though the present parties held under the parties to that litigation, the court thought the earlier decrees if not binding were persuasive. It took cognizance of the fact that pursuant to a contract

33 The court could not see how converting a stream into a dry bed could improve navigation. It noted that the sole purpose of the flood control was irrigation, not to aid navigation or control commerce.

34 Supra note 8. 
with Miller \& Lux, defendant had placed sums in escrow as compensation for numerous water rights including those involved in this case. ${ }^{85}$

Defendant argued that the 1928 amendment only preserved riparian rights to the extent that they can be beneficially used, that since the plaintiffs could not use these waters without wasting them, and that since the constitution prohibits waste, they had lost all their rights. Plaintiffs pointed out that it was no waste for the waters to flow over their lands, then on to lower riparian lands and finally to the sea where they helped to retard the encroachment of salt water; furthermore the amendment was not intended to take away a vested right.

The court upheld the plaintiffs' contentions. It found such a method of irrigation to be beneficial and reasonable and that it was not economically feasible to substitute an irrigation system. It declared: ${ }^{36}$

It would appear that plaintiffs were not deprived of all their rights as riparian owners by the amendment to the California Constitution. Apparently, they had the right to denand that defendant provide such a physical solution as would permit then to continue to receive so much of the waters of San Joaquin River as they could beneficially use; or, if such a solution was impossible, that they had the right to demand of the defendant compensation for the deprivation of the right to so much of the water they had formerly received as they could beneficially use.

The Government carried the case to the Supreme Court of the Umited States on certiorari. Seventeen western states filed a brief which included the official Califorma view as to the local law involved. The brief recoguized that the Court of Claims decision seemed "to be the normal and natural application of the law as developed by the Califorma courts since the 1928 amendment," ${ }^{3 r}$ but took exception to the statement that the plaintiffs "had the right to demand" that the defendant provide a physical solution, in the following language: ${ }^{38}$

35 The plaintiffs held their land subject to certain prior water rights of Miller \& Lux, Inc. Apparently the escrow was established because of some uncertainty as to whether Miller \& Lux, Inc. or plaintiffs should be compensated for the rights at issue.

${ }^{36}$ Gerlach Livestock Co. v. United States, supra note 31 at 95. In arriving at these conclusions the court cited the following cases: Peabody, supra note 14; City of Lodi, supra note 26; Hillside Water, supra note 25; Aitken, supra note 27; and Abbot, supra note 28 .

37 Brief of the States of California, etc. as Amicus Curise, p. 24.

38 Ibid. 
The case at bar involves, not injunction, but evaluation of a riparian right in terms of money. In such a case it is not incumbent upon the defendant to "devise some physical solution" whereby the plaintiff's needs can continue to be satisfied, but the defendant may advance such a physical solution if it so desires for the purpose of minimizimg damages, or to avoid thein entirely. It is under no "obligation" to do so. [citing the Hillside Water case. ${ }^{39}$ ]

In the cases at bar, the defendant advanced no such solution and, therefore, a discussion of the physical solution is, for present purposes, irrelevant. It is only in cases where the defendant chooses to advance a "physical solution" as a means of mitigating or avoiding damages that this factor becomes material ....

The United States Supreme Court, on June 5, 1950, affirmed the judgments of the Court of Claims, holding unanimously that the clainiants were entitled to be compensated. ${ }^{40}$ The Court rather easily disposed of the argument that no compensation was required under the comnerce clause, ${ }^{41}$ and faced the niore difficult problem of whether plaintiffs had riparian rights under California law. Referring to the "cryptic text of the amendment," Mr. Justice Jackson, for the Court, said: ${ }^{42}$

Its text leaves many questions to be answered, and neither it nor any legislation or judicial decision provides a direct and explicit determination of the present state law on issues before us. But since the federal law adopts that of the State as the test of federal liability, we must venture a conclusion as to peculiarly local law.

\section{Supra note 25.}

40 Douglas concurred in a separate opinion, dissenting to that part of the judgment which awarded interest. Black concurred in the opinion of the Court, except that he agreed with Douglas that interest should not be allowed.

41 The Court refused to decide whether Congress intended to invoke its navigation servitude as to the projects, since it concluded that, "whether required to do so or not, Congress elected to recognize any state-created rights and to take them under its power of eminent domain." United States v. Gerlach Live Stock Co., 339 U. S. at 739 (1950). It stated:

Accordingly, we need not decide whether a general declaration of purpose is controlling where interference with navigation is neither the means, ... nor the consequence, ... of its advancement elsewhere. Similarly, we need not ponder whether, by virtue of a highly fictional navigation purpose, the Government could destroy the flow of a navigable stream and carry away its waters for sale to private interests without compensation to those deprived of them. We have never held that or anything like it....Id. at 737.

42 Id. at 743. The amendment was said to compress "into a single paragraph a reconciliation and modification of doctrines evolved in litigations that have vexed [California's] judiciary for a century." Ibid. 
After making a learned exposition of the development of the law of riparian rights in California, he went on to express the reasons for holding that the deprivation of this overflow right was compensable. He pointed out that prior to reporting the amendment the joint legislative committee rejected all dispossession proposals as confiscatory. While it cannot be assumed that the amendment was without impact upon claims to water rights, neither can it be assumed that it deprives riparian owners of benefits it declares to continue.

Jackson likened riparianism to a dog-in-the-manger, since the riparian owner by injunction could enforce his bare technical right to the natural flow of the stream even if he received no substantial benefit. The constitution abolishes this "canine element" by limiting it to "such water as shall be reasonably required for the beneficial use to be served." The only hazard to plaintiffs' claims was the clause which reads: "and such right does not and shall not extend to the waste or unreasonable method of diversion of water." He was willing to assume that the improvident use, imseparable from the plaintiffs' benefits, was such that the rights asserted could not be enforced by injunction, but he emphasized: 13

Withholding equitable remedies, such as specific performance, mandatory orders or injunctions, does not mean that no right exists. There may still be a right invasion which would call for indemnification. In fact, adequacy of the latter remedy is usually grounds for denial of the former.

He reasoned that the public welfare, which requires the plaintiffs to sacrifice their benefits to the broader ones of higher utilization does not require that the loss be uncompensated any more than in other surrenders of private rights in the public interest. These plaintiffs were to be deprived of their waters for the benefit of other private land owners not riparian to the river and in a different water shed, making the lands of others more valuable and profitable. Since the reclamation law contemplates the reimbursement of the government for its outlay, why spare those who get the waters from making whole those who lose them? He posed the problem: ${ }^{44}$

Public interest requires appropriation; it does not require expropriation. We must conclude that by the Amendment California unintentionally destroyed and confiscated a recognized and adjudicated

$\$ 3$ United States v. Gerlach Live Stock Co., 339 U.S. at 752 (1950).

44 Id. at 753 . 
private property right, or that it remains compensable although no longer enforcible by injunction.

As in the Court of Claims, the superior court case of Miller \& Lux, Inc. v. Madera Irrigation District ${ }^{45}$ becomes all-important since it sustained the identical rights to the grasslands belonging to the plaintiffs. The judgments in that case have become final against the grantor of the defendant United States. Jackson refused to consider that those judgments might be res judicata, but recognized them as persuasive that the plaintiffs' rights have, in the opinion of the California courts, survived the aniendment and must be retired by condemnation or acquisition to validate the Friant diversion. He noted that the Supreme Court of Califorma had not answered the specific problem but from discussions of collateral issues in various cases concluded that the claim of plamtiffs had a sound basis in California law. ${ }^{46}$

45 Supra note 8.

46 For this proposition he cited the following cases: Peabody, supra note 14; City of Lodi, supra note 26; Hillside Water, supra note 25; Gin S. Chow, supra note 9; Meridian, supra note 22; and City of Los Angeles v. City of Glendale, 23 Cal. 2d 68, 142 P.2d 289 (1943). The only post-amendment case discussed was the Miller \& Lux superior court case, supra note 8.

Jackson recognized the asserted right to inundation to be unique in the history of riparian claims, but declared:

Where the thirst of the land is supplied by rainfall, floods are detriments if not disasters, and to abate overflows could rarely if ever cause damage. But, as we have pointed out, uncommon local conditions have given rise to the singular rule of California. The saine scarcity which makes it advantageous to take these waters gives them value in the extraordinary circumstances in which the California courts have recognized a private right to have no interception of their flow except upon compensation. United States v. Gerlach Live Stock Co., 339 U.S. at 754-755 (1950).

The decision will not materially burden the Central Valley Project. Froin the start the Bureau of Reclamation has bought such rights and in 1950 it reported the expenditure to June 30,1949 of $\$ 5,377,498$ for water rights, of an estimated total of $\$ 6,150,000$ to be expended. This seems small in coniparison to the present estimated cost of $\$ 411$,000,000 for the entire project. The Bureau has announced its approval of the decision.

The meaning and effect of the 1928 Constitutional Amendment was also referred to in Rank v. Krug, 90 F. Supp. 773 (S.D. Cal. 1950). This case arose out of the Central Valley Project upon a motion to dismiss a complaint by riparian owners alleging the intention of the Government to take all of the water of the river. The case, therefore, at that stage did not involve the question of the right of the riparian owners to the benefit of overflow. The court, however, made certain suggestions as to the meaning and effect of the amendment, and stated that it enlarged the previous provision of the Constitution of 1879 , Section 1, Article XIV, that the "sale, rental, or distribution" of water was a public use and, in effect, said that the use of all water in the State of Califormia was a public use. No basis can be found for this statement. The court further 
The future will raise more perplexing problems as to what is a reasonable method of diversion and use of water under the 1928 amendment, and conversely what constitutes waste in a legal sense. These problems can arise under almost an infinite variety of circumstances involving questions of both law and fact. The appellate courts have generally refused to pass on these matters except as they are presented in concrete cases and it is not intended here to pass upon sets of facts which have not yet received the attention of the courts. ${ }^{47}$

A few of the circumstances under which this problem may arise follow:

(1) The water of a stream may percolate underground and supply a body of underground water from which the landowner pumps water for beneficial uses. The maintenance of this body of water may require the hydraulic force of the stream at an elevation sufficiently high to irrigate the land or to make it feasible to pump water for its irrigation.

(2) A riparian owner may have constructed works for the production of power, which are operated by the natural flow of a stream at high stages, but not if the natural flow is greatly reduced.

(3) A landowner may be situated entirely on a branch or slough channel of a river and water ouly reaches his land when a large quantity of water flows im the main stream. The question could arise as to whether he can insist upon the large flow in order that a small quantity of water can flow to his lands.

(4) By the construction of concrete-lined ditches at a considerable expense many irrigators can save a large amount of water which is otherwise lost by percolation.

How the courts will solve these problems remains to be seen. The

stated that the amendment means that riparian owners can claim no more than the rights guaranteed them by law to use water of the stream for all the present, prospective, reasonably useful, and beneficial purposes, and adopt means made available to them thereby to protect such rights.

4r One writer suggested that an interesting variation of the Gerlach case might arise if the appropriator under the facts were a private party:

In effect, this would be a rehearing of the Herminghans case in the light of the 1928 amendment. The cases indicate that the riparian right would attach, and that compensation would be granted to the riparian. However, if the purpose of the 1928 amendment were to be respected, an injunction against the upstream appropriator would be demied where the riparian use was wasteful. Instead of an injunction, the riparian should be required to change his method of use, e.g., install a pumping system, probably at the expense of the appropriator, or accept compensation in lieu of the physical flow. Comment, 1 STAN. L. REv. 172,177 (1948). 
earlier cases will be helpful in their solution, and it can safely be said that the courts will be realistic in solving them. Due regard will be given to the established rule that injunctions will not be granted where compensation is adequate; that physical solutions will be devised if possible; and that generally the expense of installing a different system for handling the water will have to be paid by the subsequent appropriator rather than by a riparian owner or prior-appropriator. 